\title{
Comparison of one-handed C-E technique and glass holding technique of mask ventilation in anesthetized, apnoeic paediatric patients
}

\author{
Rahul Katiyar', Shashi Prakash ${ }^{2 *}$,Sulakshana Tripathi ${ }^{3}$, Rajesh Meena ${ }^{4}$, Sandeep Loha ${ }^{4}$, \\ Pushkar Ranjan ${ }^{5}$ \\ Junior Resident ${ }^{1}$, Associate Professor ${ }^{2}$, Senior Resident ${ }^{3}$, Assistant Professor ${ }^{4}$, Professor ${ }^{5}$, \\ Department of Anaesthesiology, Institute of Medical Sciences, Banaras Hindu University, Varanasi, \\ India.
}

\begin{abstract}
Background: Successful and effective ventilation using a face mask is very basic, important and critical step in emergency resuscitation as well as in the operating room for preoxygenation of anesthetized apnoeic patients. Mask ventilation requires a good seal and a patent airway. Techniques for face mask ventilation include one-handed techniques and twohanded techniques. One-handed technique can be either classical C-E technique or glass holding technique. We aim to compare two one-handed techniques of mask holding in terms of delivered ventilation, mask leak and ease of performing.
\end{abstract}

Method: All patients fulfilling inclusion and exclusion criteria were included after approval of the institutional ethics committee. After induction of general anaesthesia and confirming apnoea, patients with an odd serial number were first started with one-handed C-E technique then crossed over with glass holding technique while patients having even serial numbers were ventilated first with glass holding technique followed by the one-handed C-E technique. Expiratory tidal volume (VTe) and peak inspiratory pressure (PIP) and ease of ventilation for each breath in one minute were recorded.

Results: VTe (mean \pm SD) ml, Leak (mean \pm SD) ml, PIP (mean \pm SD) $\mathrm{cmH} 2 \mathrm{O}$ was $94.94 \pm 25.22,21.36 \pm 7.97,18.05 \pm 2.99$ and $101.78 \pm 28.18,19.78 \pm 15.68,16.52 \pm 1.95$ for $\mathrm{CE}$ and Glass holding technique respectively. There is no significant difference between both the techniques in terms of analysed variables. ( $p$-value $>0.05$ )

Conclusion: Statistical analysis does not support that Glass holding technique is better than $\mathrm{C}-\mathrm{E}$ technique in respect to studied variables. Still as results were comparable for both the groups, the Glass holding technique is a good alternative to $\mathrm{C}-\mathrm{E}$ and other techniques of mask ventilation. Glass holding technique is very promising in view of ease of ventilation, decreasing procedural fatigue and reducing incidence and severity of tissue trauma, but further studies are required.

Keywords: mask ventilation; C-E technique; glass holding technique; anaesthesiology

\section{Introduction}

Successful and effective ventilation using a face mask is very basic, important and critical step in emergency resuscitation as well as in the operating room for pre-oxygenation of anesthetized apnoeic patients. Adequate ventilation along with maintaining good

*Correspondence: Shashi Prakash

E mail: dr.shashi.prakash@gmail.com

https://orcid.org/0000-0003-3609-4398

Received: $24 / 08 / 2018$

Accepted:15/01/2019

DOI: http://doi.org/10.4038/slja.v27i1.8372

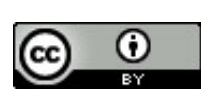

perfusion are two critical factors which determine the positive outcome in successful resuscitation. ${ }^{1}$ In the operating room, mask ventilation is used for pre-oxygenation of anaesthetized apnoeic patients. At adequate flow, $100 \%$ oxygen in breathing circuit is maintained using effective face mask seal to increases the oxygen reserve and achieve denitrogenation which gives valuable additional time for laryngoscopy, tracheal intubation, and for airway rescue if laryngoscopy or intubation fails. For optimal preoxygenation, recommended $\mathrm{EtO}_{2}$ values are $>90 \%{ }^{2,3}$ In healthy adults, optimal preoxygenation can extend the duration of apnoea without desaturation (i.e. the interval between the onset of apnoea till peripheral capillary oxygen saturation falls up to a value of $\leq 90 \%$ ) to up to 
8 mins which is otherwise limited to $1-2 \mathrm{~min}$ without pre-oxygenation. ${ }^{4}$ Thus face-mask ventilation can be a lifesaving backup plan to bridge attempts at intubation, prior to establishing a supraglottic airway or before progressing to the surgical airway.

Mask ventilation requires a good seal and a patent airway. Good technique and proper practice of this important skill increases the clinician's ability to provide effective ventilation. There are various techniques for face mask ventilation, which include the one-handed techniques and the two-handed techniques. One-handed technique can be either classical C-E technique or glass holding technique. The classical $\mathrm{C}$-E technique involves thumb and index finger to form a " $\mathrm{C}$ " on the mask surface to maintain an adequate seal and the little, ring and middle finger form an " $E$ " on the mandible for jaw lift while glass holding technique involves index finger and thumb to form a seal with the mask in a way similar to classical C-E clamp technique, but using the other three fingers and rest of the palmar surface of the hand to engulf the under-surface of the chin or the mandible, very much like holding a glass. ${ }^{5}$

There are studies which compare one-handed technique with the two-handed technique of mask ventilation. ${ }^{6}$ Although single handed face mask ventilation is more practical and most commonly used method, still no study effectively compares the efficacy of ventilation among single handed techniques. So, with this study, we aim to compare two one-handed techniques of mask holding in terms of delivered ventilation, mask leak and ease of performing.

\section{Objectives}

1. To assess the efficacy of one-handed C$\mathrm{E}$ technique and glass holding technique of mask ventilation

2. To find out the better technique of mask ventilation among these techniques

3. To study the effect of one technique (when used before) over another technique

\section{Material and methods}

Study Design: After approval by the Institutional review board, a prospective, randomized, crossover study, was conducted in the department of paediatric anaesthesia, IMS, Banaras Hindu
University, Varanasi, India. The study was conducted between months of October 2017 to April 2018. Sample size of total 120 paediatric patients of 1 year to 10 years of age, who were scheduled for elective surgery under general anaesthesia, were included in the study. A day before the scheduled surgery all the patients were assessed for eligibility and parents of all study participants were briefly described about the study and only patients whose parents were ready to give written consent were included in the study.

Exclusion criteria: Patients who were undergoing emergency surgery, or were planned for surgery of face/neck, patients with anticipated difficult mask ventilation or any facial trauma or facial deformity, patients having any cardiac or respiratory disease, patients with a full stomach or patients with high risk of aspiration, patients planned for rapid sequence induction or having any contraindication of bag-mask ventilation, patients who were induced with different drugs and patients whose parents did not give consent to participate in study, were excluded from study.

Sample size: Based on the study published in $2013^{7}$ Vte (expiratory tidal volume) was used to calculate the sample size. With the level of significance $5 \%$, at one tail test, with $80 \%$ power, yielding an expected sample size of 111 . We planned to enrol a total of 120 subjects.

Study protocol: On the day of surgery, patients were taken to the operating room and a brief quick re-assessment was done as per inclusion and exclusion criteria mentioned in the study. All the ASA monitors were attached. On the study case sheet patient's age, sex, height, weight, and ASA physical status along with the baseline haemodynamic parameters were noted. For randomization of study subjects, all the patients with an odd serial number were first started with one-handed C-E technique than crossed over with glass holding technique while all the other patients who were having even serial number were ventilated first with glass holding technique followed by one-handed C-E technique. To avoid investigator bias mask ventilation was performed by anaesthesiologists who were not part of study and investigator present in the operating room was recording the required data on a study case sheet. 


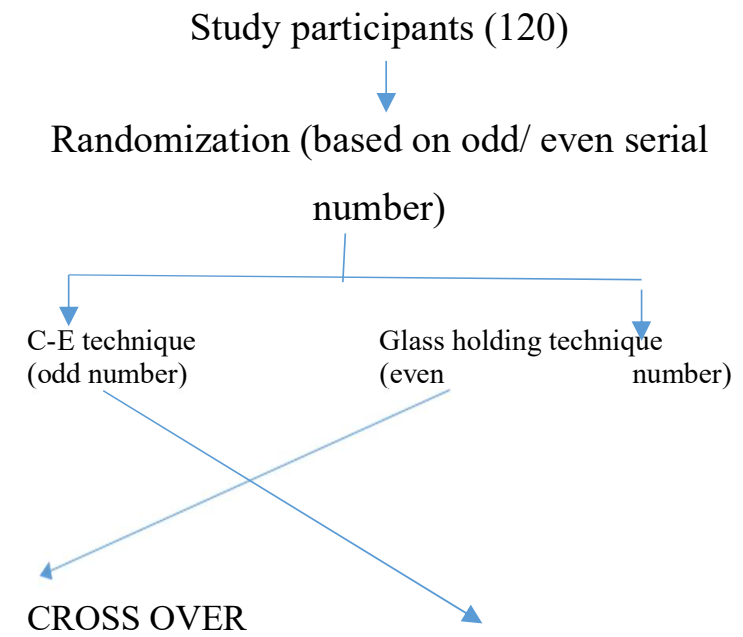

$\mathrm{C}$-E technique (even number) Glass holding technique (odd number)

Patients were induced with fentanyl $1-3 \mathrm{mcg} / \mathrm{kg}$, propofol $2-3 \mathrm{mg} / \mathrm{kg}$ and cis-atracurium $0.15-$ $0.2 \mathrm{mg} / \mathrm{kg}$ to achieve apnoea. Once apnoea was confirmed, patients were first checked for ability to ventilate with an optimum sized mask and proper seal. Patients were then put on the ventilator in anaesthesia machine (DatexOhmeda Avance; S/5 aespire) which was preset in volume control mode at the tidal volume of 10 $\mathrm{ml} / \mathrm{kg}$, respiratory rate $20 / \mathrm{min}$, I:E ratio $1: 2$ and no positive end-expiratory pressure. Now anaesthesiologist was asked to hold a mask with either of two technique of mask ventilation depending on serial number provided to the patient. Expiratory tidal volume (VTe) and peak inspiratory pressure (PIP) for each breath in one minute were recorded by an investigator. Then, anaesthesiologist was asked to switch the technique of mask ventilation and again VTe and PIP readings were noted with each breath for the next one minute.

Collected data from all the patient's case sheet were then compiled in a study record sheet and taken for statistical analysis using SPSS-23 software. Descriptive frequencies were expressed using mean (standard deviation) and median (range). Difference between means of continuous variables were compared using the unpaired student $t$ test and analysis of variance, as applicable, and that of categorical variables with the Chi -Square test. The critical value of 'p' indicating the probability of significant difference was taken as $<0.05$ for comparison.

\section{Results}

The study was conducted in the department of paediatric anaesthesiology, 120 participants, eligible as per inclusion and exclusion criteria, were enrolled in the study. Six participants were dropped from the study because parents of one participant withdrew consent in the morning of surgery, in two participants different medications were used and two-handed technique of mask ventilation had to be used in three patients. After excluding these patients, a total of 114 participants were analysed for final results. Participants were classified in two groups, patients in whom CE technique was used first (with an odd serial number) were kept in group A and patients in whom glass holding technique was used first were classified in group B. Both the groups were matched in various variable scales. (Table 1).

Table 1: Participant characteristics

\begin{tabular}{|l|l|l|l|l|}
\hline & $\begin{array}{l}\text { GROUP } \\
\text { A } \\
\text { C-E first } \\
(57)\end{array}$ & $\begin{array}{l}\text { GROUP } \\
\text { B } \\
\text { Glass } \\
\text { holding } \\
\text { first (57) }\end{array}$ & $\begin{array}{l}\text { Test } \\
\text { value }\end{array}$ & $\begin{array}{l}\mathrm{p} \\
\text { value }\end{array}$ \\
\hline $\begin{array}{l}\text { Age } \\
\text { (mean) }\end{array}$ & $5.27 \mathrm{yrs}$ & $4.33 \mathrm{yrs}$ & 1.13 & 0.272 \\
\hline $\begin{array}{l}\text { Gender } \\
\text { (M:F) }\end{array}$ & $32: 25$ & $35: 22$ & 0.460 & 0.498 \\
\hline $\begin{array}{l}\text { Weight } \\
\text { (mean) }\end{array}$ & $\begin{array}{l}15.10 \\
\mathrm{kgs}\end{array}$ & $14.11 \mathrm{kgs}$ & 0.571 & 0.575 \\
\hline ASA & I\&।I & $1 \& \mathrm{I}$ & & \\
\hline
\end{tabular}

Group A - patients in which C-E technique was used first

Group B - patients in which Glass holding technique was used first

Patients of Group A (57) were first ventilated with $\mathrm{CE}$ technique for one minute followed by Glass holding technique for next minute at VTe $93.20 \pm 27$, leak $25.80 \pm 6.17$, PIP $18.50 \pm$ 3.13 and VTe $104.70 \pm 29.62$, leak $24.30 \pm 14.9$, PIP $16.80 \pm 2.09$ respectively. Patients of Group B (57) were first performed with Glass holding for one minute followed by $\mathrm{CE}$ technique for next minute with VTe $98.55 \pm 27.88$, leak $14.77 \pm$ 7.71, PIP $16.22 \pm 1.85$ and VTe $96.88 \pm 22.06$, leak $16.44 \pm 6.94$, PIP $17.55 \pm 2.92$ respectively. 
Comparison between group $A$ and B: Outcome measures were VTe, mask leak and PIP. Mean $\mathrm{VTe}$ was more in techniques being performed after crossover but results were statistically insignificant. ( $p$-value $>0.05$ ). There is no difference in PIP between groups. (Table 2 and Table 3)

Table 2: Comparison of CE technique between group A and group B

\begin{tabular}{|c|c|c|c|c|}
\hline Variables & $\begin{array}{l}\text { CE } \\
\text { (Group } \\
\text { A) }\end{array}$ & $\begin{array}{l}\text { CE } \\
\text { (Group } \\
\text { B) }\end{array}$ & $\begin{array}{l}T \\
\text { test }\end{array}$ & $\begin{array}{l}\mathbf{p} \\
\text { value }\end{array}$ \\
\hline $\begin{array}{l}\mathrm{VTe} \\
(\mathrm{mean} \pm \mathrm{SD} \\
) \mathrm{ml}\end{array}$ & $\begin{array}{l}93.20 \pm \\
27.4\end{array}$ & $\begin{array}{l}96.88 \pm \\
22.06\end{array}$ & 0.310 & 0.760 \\
\hline $\begin{array}{l}\text { Leak } \\
\text { (mean } \pm \text { SD } \\
\text { ) } \mathrm{ml}\end{array}$ & $\begin{array}{l}25.80 \pm \\
6.17\end{array}$ & $\begin{array}{l}16.44 \pm \\
6.94\end{array}$ & 1.765 & 0.096 \\
\hline $\begin{array}{l}\text { PIP } \\
(\text { mean } \pm \text { SD) } \\
\mathrm{cm} \mathrm{H} \text { HO }\end{array}$ & $\begin{array}{l}18.50 \pm \\
3.13\end{array}$ & $\begin{array}{l}17.55 \pm \\
2.92\end{array}$ & 0.677 & 0.508 \\
\hline
\end{tabular}

Table 3: Comparison of Glass holding technique between group A and group B

\begin{tabular}{|l|l|l|l|l|}
\hline Variables & $\begin{array}{l}\text { Glass } \\
\text { holding } \\
\text { (Group B) }\end{array}$ & $\begin{array}{l}\text { Glass holding } \\
\text { (Group A) }\end{array}$ & $\begin{array}{l}\text { T } \\
\text { test }\end{array}$ & $\begin{array}{l}\mathbf{p} \\
\text { valu } \\
\text { e }\end{array}$ \\
\hline $\begin{array}{l}\text { VTe } \\
(\text { mean } \pm \text { SD) } \\
\text { ml }\end{array}$ & $98.55 \pm 7.88$ & $104.7 \pm 29.62$ & 0.46 & 0.64 \\
4 & 9 \\
\hline $\begin{array}{l}\text { Leak } \\
(\text { mean } \pm \text { SD) } \\
\text { ml }\end{array}$ & $14.77 \pm 7.71$ & $24.30 \pm 14.9$ & 0.79 & 0.43 \\
\hline $\begin{array}{l}\text { PIP } \\
(\text { mean } \pm S D) \\
\text { cm H2O }\end{array}$ & $16.22 \pm 1.85$ & $16.80 \pm 2.09$ & 0.63 & 0.53 \\
\hline
\end{tabular}

Figure1: Box plots showing median values (solid bar), interquartile range (margins of box), range of data, and any extreme values (indicated by an asterisk).

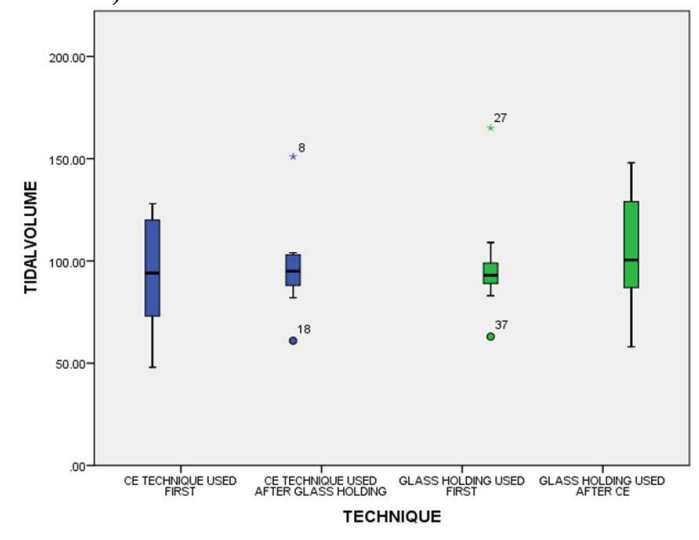

Comparison between $\mathrm{CE}$ technique and Glass holding technique: Outcome measures were $\mathrm{VTe}$, mask leak and PIP. VTe (mean $\pm \mathrm{SD}) \mathrm{ml}$, Leak (mean \pm SD) ml, PIP $\left(\right.$ mean \pm SD) $\mathrm{cmH}_{2} \mathrm{O}$ was $94.94 \pm 25.22,21.36 \pm 7.97,18.05 \pm 2.99$ and $101.78 \pm 28.18,19.78 \pm 15.68,16.52 \pm 1.95$ for CE and Glass holding technique respectively. There is no significant difference between both the techniques in terms of analysed variables. ( $p$ value $>0.05$ ). Table 4 and Figure 2.

Table 4: Comparison between CE technique and Glass holding technique

\begin{tabular}{|c|c|c|c|c|}
\hline Variables & $\begin{array}{l}\text { CE } \\
\text { technique } \\
(\mathrm{A}+\mathrm{B} \\
=114)\end{array}$ & $\begin{array}{l}\text { Glass } \\
\text { holding } \\
\text { technique } \\
\text { (A+B- } \\
=114)\end{array}$ & T test & $\begin{array}{l}p \\
\text { value }\end{array}$ \\
\hline $\begin{array}{l}\text { VTe } \\
(\text { mean } \pm \text { SD) } \\
\text { ml }\end{array}$ & $\begin{array}{l}94.94 \pm \\
25.22\end{array}$ & $\begin{array}{ll}101.78 \quad \pm \\
28.18\end{array}$ & -0.788 & 0.436 \\
\hline $\begin{array}{l}\text { Leak } \\
(\text { mean } \pm \text { SD) } \\
\text { ml }\end{array}$ & $\begin{array}{ll}21.36 & \pm \\
7.97 & \end{array}$ & $\begin{array}{ll}19.78 & \pm \\
15.68 & \end{array}$ & 0.256 & 0.799 \\
\hline $\begin{array}{l}\text { PIP } \\
\text { (mean } \pm \text { SD) } \\
\mathrm{cm} \mathrm{H}_{2} \mathrm{O}\end{array}$ & $\begin{array}{ll}18.05 \quad \pm \\
2.99\end{array}$ & $\begin{array}{ll}16.52 & \pm \\
1.95 & \end{array}$ & 1.862 & 0.071 \\
\hline
\end{tabular}

Figure 2: Box plots showing median values (solid bar), interquartile range (margins of box), range of data, and any extreme values (indicated by an asterisk).

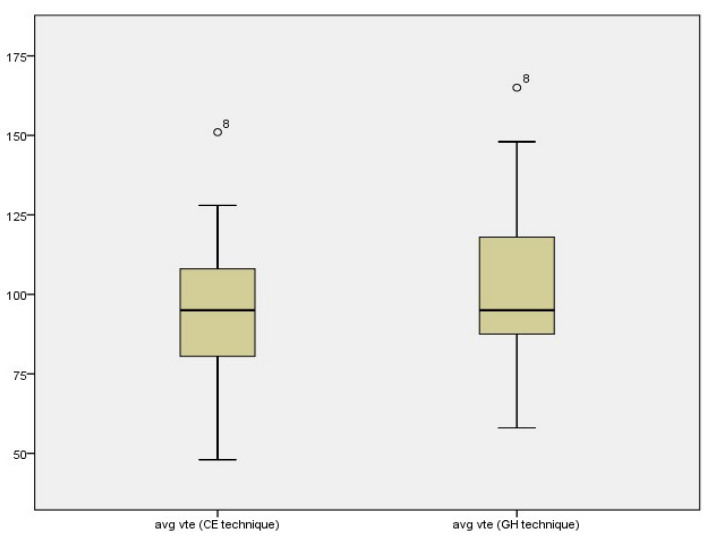

\section{Discussion}

Although there was no difference in mean expiratory tidal volume, leak and peak inspiratory pressure between both the techniques and statistical analysis does not support that Glass holding technique is better than C-E technique in respect to studied variables. Still as results were comparable for both the groups, the Glass holding technique is a good alternative to C-E and other techniques of mask ventilation. This technique is very easy to learn and perform, there was less 
procedure fatigue, less soft tissue trauma and less temporomandibular dislocation.

Also in this study, two groups were made for each technique, in one group one technique was used for initial first minute and in second group this technique was used after one minute ventilation via other technique. For both the techniques, in the latter groups mean expiratory tidal volume was more and leak was less than the former groups. But this comparison was also statistically insignificant ( $\mathrm{p}$ value $>0.05$ ), this means that after 3 minutes of used muscle relaxant, mask ventilation performance is neither influenced by increasing time nor by previously used ventilation technique.

\section{Conclusion}

Mask ventilation is a critical technique that requires mastering, so the technique which is easy to learn and perform should be easy to master too. Glass holding technique is good alternative to other techniques of mask ventilation. Expiratory tidal volume and mask leak is statistically similar in both the studied techniques, but investigator also found that Glass holding technique is very promising in view of ease of ventilation, decreasing procedural fatigue and reducing incidence and severity of various tissues trauma, but further studies are required to establish this as a fact.

\section{References}

1. Morley CJ, Davis PG. Advances in neonatal resuscitation: supporting transition.Arch Dis Child Fetal Neonatal Ed 2008;93:F334-6. https://doi.org/10.1136/adc.2007.128827 PMid: 18450801

2. Berry CB, Myles PS. Preoxygenation in healthy volunteers: a graph of oxygen "washin" using end-tidal oxygraphy. Br J Anaesth 1994; 72: $116-8$.

https://doi.org/10.1093/bja/72.1.116

3. Campbell IT, Beatty PC. Monitoring preoxygenation. Br J Anaesth 1994; 72: 3-4. https://doi.org/10.1093/bja/72.1.3 PMid:8110546

4. Tanoubi I, Drolet P, Donati F. Optimizing preoxygenation in adults. Can J Anaesth 2009; 56: $449-66$

https://doi.org/10.1007/s12630-009-9084-z PMid: 19399574

5. Prakash S, Dhar M, Ranjan P, Gupta B, Pai V. Glass holding technique for bag and mask ventilation: An alternative in neonates and infants. Saudi Journal of Anaesthesia. 2016;10(4):487-488. doi:10.4103/1658354X.177342. https://doi.org/10.4103/1658-354X.177342

6. Joffe AM, Hetzel S, Liew EC. A two-handed jaw-thrust technique is superior to the onehanded "EC-clamp" technique for mask ventilation in the apneic unconscious person. Anesthesiology. 2010;113:873-9.

https://doi.org/10.1097/ALN.0b013e3181ec641 $\underline{4}$

PMid:20808210

7. Hart D, Reardon R, Ward C, Miner J. Face mask ventilation: a comparison of three techniques. J Emerg Med. 2013 May;44(5):1028-33. https://doi.org/10.1016/j.jemermed.2012.11.005 PMid:23473817 